\title{
PROFIL KADAR ASAM URAT PADA REMAJA OBES DI KOTA BITUNG
}

\author{
${ }^{1}$ Eggy P.J. Ngantung \\ ${ }^{2}$ Aaltje E.Manampiring \\ ${ }^{2}$ Widdhi Bodhi \\ ${ }^{1}$ Kandidat Skripsi Fakultas Kedokteran Universitas Sam Ratulangi Manado \\ ${ }^{2}$ Bagian Kimia Fakultas Kedokteran Universitas Sam Ratulangi Manado \\ Email: Eggyngantung12027@yahoo.com
}

\begin{abstract}
Uric acid is an end product of purine metabolism in humans. Serum uric acid levels increased significantly to those who are obese. In people who have a form of body fat tend to be more easily and have a high risk of gout due to decomposition of food with high level of purine and fats that mixed in blood is difficult to excreted through urine, resulting in the accumulation and clogging fats in the blood. This study aims to describe uric acid in obese adolescents. This research is a descriptive cross sectional approach. The sampling technique used is the technique of random sampling. Samples were taken from the high school students in the city of Bitung that obesity is determined by measuring waist circumference. Then students who are willing to be sampled were asked to sign an informed consent and fasting of at least 10-12 hours, then take the blood for examination of blood uric acid levels. The prevalence of adolescents obesity that have uric acid increased in Bitung is 56\%. In research conducted on 50 students of obesity, found $28(56 \%)$ of people have increased uric acid, which consists of 8 (16\%) persons of male students and $20(40 \%)$ persons of female students.
\end{abstract}

Keyword : uric acid, obecity

\begin{abstract}
Abstrak: Asam urat merupakan produk akhir metabolisme purin pada manusia. Kadar asam urat serum meningkat secara signifikan terhadap mereka yang mengalami obesitas. Pada orang yang memiliki bentuk tubuh gemuk cenderung lebih mudah dan memiliki resiko tinggi terkena penyakit asam urat karena proses penguraian makanan purin yang bercampur lemak dalam darah sulit dikeluarkan melalui urine, sehingga terjadi penumpukan dan penyumbatan lemak dalam darah. Penelitian ini bertujuan untuk mengetahui gambaran asam urat pada remaja obesitas. Penelitian ini berupa cross sectional dengan pendekatan deskriptif. Teknik pengambilan sampel yang digunakan adalah dengan teknik random sampling. Sampel penelitian diambil dari siswa-siswi SMA dikota Bitung yang obesitas yang ditentukan dengan mengukur lingkar pinggang. Kemudian siswa yang bersedia dijadikan sampel diminta untuk menandatangani informed consent dan melakukan puasa minimal 10-12 jam, kemudian diambil darah untuk dilakukan pemeriksaan kadar asam urat dalam darah. Prevalensi remaja obesitas yang mengalami peningkatan asam urat di Kota Bitung adalah 56\%. Dalam penelitian yang dilakukan pada 50 siswa obesitas, didapatkan 28 (56\%) orang mengalami peningkatan asam urat, yang terdiri dari 8 (16\%) siswa laki-laki dan 20 (40\%) siswa perempuan.
\end{abstract}

Kata kunci : asam urat, obesitas 
Asam urat merupakan gangguan metabolik yang sudah dikenal oleh Hipokrates pada zaman Yunani kuno. Pada waktu itu asam urat dianggap sebagai penyakit kalangan sosial elit yang disebabkan karena terlalu banyak makan dan minum anggur. ${ }^{1}$ Asam urat adalah hasil produksi oleh tubuh, sehingga keberadaanya bisa normal dalam darah dan urin. Akan tetapi sisa dari metabolisme protein makanan yang mengandung purin juga bisa menghasilkan asam urat. Oleh karena itulah kadar asam urat dalam darah bisa meningkat bila seseorang terlalu banyak mengkonsumsi makanan yang mengandung purin tinggi. ${ }^{2}$

Di Indonesia, penyakit asam urat bahkan terjadi pada usia muda. Hasil data penelitian yang dilakukan seperti Manampiring AE (2011) di Kota Tomohon didapatkan prevalensi peningkatan asam urat pada remaja obese di Kota Tomohon adalah sebesar $35 \%$. Penyebab meningkatnya kadar asam urat dipengaruhi oleh berbagai macam faktor contohnya alkohol, genetik, hipotiroid, obesitas, diet tinggi purin. ${ }^{3}$

Di Indonesia, penyakit asam urat menduduki peringkat kedua terbanyak setelah osteoarthritis, penyakit ini berhubungan dengan tingginya kadar asam urat darah (hiperurisemia). Penyakit asam urat erat kaitannya dengan obesitas. Pola hidup kurang olahraga, konsumsi makanan berlemak, berkadar gula tinggi, daging merah, jeroan dan santan. ${ }^{4}$ Kebiasaan makan yang tidak sesuai kaidah sehat maka dapat mengakibatkan berbagai macam gangguan kesehatan. Kebiasaan makan yang tidak sehat dalam memilih jenis makanan juga dapat berdampak pada masalah kelebihan berat badan (overweight) dan berakhir dengan obesitas. $^{5}$

Obesitas terjadi karena adanya ketidakseimbangan antara energi yang masuk dengan energi yang keluar. Sedangkan menurut Dariyo (2004) yang dimaksud dengan obesitas adalah kelebihan berat badan dari ukuran normal sebenarnya. Masa remaja adalah masa yang menyenangkan, namun juga masa yang kritis dan sulit, karena merupakan masa transisi atau peralihan dari masa kanak-kanak menuju masa dewasa, yang ditandai dengan perubahan aspek fisik, psikis, dan psikososial (Dariyo, dalam Galih Tri Utomo 2012). ${ }^{6}$ Prevalensi obesitas pada anak dan remaja semakin meningkat dari tahun ke tahun baik di dunia, di Asia maupun di Indonesia. Prevalensi obesitas di Indonesia menurut data Riset Kesehatan Dasar tahun 2007, penduduk usia 15 tahun atau lebih adalah 10,3\%, sedangkan Jawa Barat prevalensi berat badan berlebih pada anak usia 6-14 tahun laki-laki 7,4\% dan perempuan 4,6\%. ${ }^{7}$ Menurut data Riskesdas 2013 obesitas pada anak usia 13-15 tahun presentasenya 10,8\%. ${ }^{8}$ Prevalensi tertinggi untuk obesitas adalah di Provinsi Sulawesi Utara $(37,1 \%)$, dan yang terendah adalah $(13,0 \%)$ di provinsi Nusa Tenggara Timur. $^{9}$

Berdasarkan latar belakang ini maka peneliti merasa perlu dan tertarik untuk melakukan penelitian tentang profil kadar asam urat pada remaja obesitas.

\section{METODE PENELITIAN}

Penelitian ini bersifat cross sectional dengan pendekatan deskriptif. Penelitian ini dilakukan di SMA dikota Bitung, penelitian dilakukan pada bulan Oktober 2015 sampai dengan Januari 2016. Populasi adalah siswa yang berusia 13-18 tahun di SMA Kota Bitung, dan sampel adalah siswa yang tergolong obesitas di SMA Kota Bitung. Pengambilan sampel menggunakan cara simple random sampling. Kriteria inklusi yaitu siswa SMA yang berusia 13-18 tahun yang sehat, terdaftar dan aktif mengikuti kegiatan sekolah, bersedia dijadikan sampel penelitian dan yang telah berpuasa 10-12 jam. Kriteria eksklusi yaitu siswa SMA yang sedang sakit dan yang berumur 
$<12$ tahun dan $>18$ tahun. Adapun definisi operasional dari kadar asam urat normal pada remaja laki-laki adalah $6,4 \mathrm{mg} / \mathrm{dL}$ dan pada remaja perempuan $4,9 \mathrm{mg} / \mathrm{dL}$ (Hongo M. 2011), obesitas adalah siswa yang memiliki lingkar pinggang $>90 \mathrm{~cm}$ untuk laki-laki dan $>80 \quad \mathrm{~cm}$ untuk perempuan (International Diabetes Federation, 2005), dan remaja adalah seseorang yang berumur 13-18 tahun (Hurlock. 1981). Cara pengambilan sampel adalah dengan mengukur lingkar pinggang, kemudian dilakukan pengambilan sampel darah untuk pemeriksaan asam urat. Sampel darah yang telah diambil dibawa ke laboratorium untuk diperiksa. Data yang diperoleh dikumpulkan dan diolah secara manual dan dikomputerisasi serta disajikan dalam bentuk tabel.

\section{HASIL PENELITIAN}

Penelitian dilakukan sejak bulan November 2015 - Januari 2016 di empat sekolah yaitu SMA Negeri 1 Bitung, SMA Negeri 2 Bitung, SMA Kristen Tumou Tou Girian dan SMA Katolik Don Bosco Bitung. Pada awal penelitian, peneliti terlebih dahulu membuat surat persetujuan penelitian yang ditandatangani oleh kepala bagian Kimia Fakultas Kedokteran Universitas Sam Ratulangi Manado. Kemudian surat tersebut diserahkan kepada kepala-kepala sekolah dari keempat sekolah tersebut untuk mendapatkan izin agar dapat melaksanakan penelitian.

Pada penelitian yang dilakukan dengan melakukan pengukuran lingkar pinggang secara acak terhadap 966 orang siswa. Ditemukan 220 siswa obesitas. Kemudian diambil secara acak 50 siswa yang obesitas sebagai sampel penelitian untuk melihat kadar asam urat dalam darah.
Tabel 1. Prevalensi obesitas pada remaja di Kota Bitung

\begin{tabular}{|c|c|c|c|c|c|}
\hline \multirow{3}{*}{ No } & \multicolumn{2}{|l|}{ Jenis } & & & \multirow{3}{*}{$\%$} \\
\hline & Kelamin & $\mathrm{N}$ & \multicolumn{2}{|c|}{ Lingkar Pinggang } & \\
\hline & & & $\begin{array}{c}\text { Normal } \\
(\%)\end{array}$ & $\begin{array}{c}\text { Obesitas } \\
\text { (\%) }\end{array}$ & \\
\hline 1 & Laki-Laki & 382 & $323(33,4 \%)$ & $59(6,10 \%)$ & $100 \%$ \\
\hline \multirow[t]{2}{*}{2} & Perempuan & 584 & $423(43,8 \%)$ & $161(16,7 \%)$ & $100 \%$ \\
\hline & & 966 & $746(77,2 \%)$ & $220(22,8 \%)$ & $100 \%$ \\
\hline
\end{tabular}

Tabel 2. Prevalensi asam urat pada remaja obesitas di Kota Bitung

\begin{tabular}{|c|c|c|c|c|c|}
\hline \multirow[b]{2}{*}{ No } & Jenis & & & & \\
\hline & Kelamin & $\mathrm{N}$ & $\begin{array}{c}\text { Normal } \\
\text { (\%) }\end{array}$ & $\begin{array}{c}\text { Meningkat } \\
\text { (\%) }\end{array}$ & $\%$ \\
\hline 1 & Laki-Laki & 12 & $4(8 \%)$ & $8(16 \%)$ & $100 \%$ \\
\hline \multirow[t]{2}{*}{2} & Perempuan & 38 & $118(36 \%)$ & $20(40 \%)$ & $100 \%$ \\
\hline & & 50 & 222 (44\%) & $28(56 \%)$ & $100 \%$ \\
\hline
\end{tabular}

Pada penelitian yang dilakukan terdapat 966 siswa yang terdiri dari 382 siswa laki-laki dan 584 siswa perempuan. Kemudian dilakukan pemeriksaan obesitas dengan mengukur lingkar pinggang. Pada pengukuran lingkar pinggang siswa yang dikatakan obesitas adalah 220 orang siswa. Kemudian diambil 50 orang siswa obesitas yang bersedia mengikuti pemeriksaan darah, yang terdiri dari 12 orang siswa laki-laki dan 38 orang siswa perempuan. Pada pengukuran yang melibatkan siswa obesitas sebagai sampel untuk pemeriksaan darah didapatkan 28 (56\%) siswa yang memiliki kadar asam urat melebihi batas normal.

\section{BAHASAN}

Pada penelitian yang melibatkan 966 siswa yang dipilih secara acak, ditemukan 22,8\% siswa obesitas yang terdiri dari $6,10 \%$ siswa laki-laki dan $16,7 \%$ siswa perempuan (Tabel 1). Obesitas disebabkan oleh ketidakseimbangan antara jumlah energi yang masuk dengan yang dibutuhkan oleh tubuh untuk berbagai fungsi biologis 
seperti pertumbuhan fisik, perkembangan, aktifitas, dan pemeliharaan.

Jika keadaan ini berlangsung terus menerus dalam jangka waktu cukup lama, maka dampaknya adalah obesitas. Beberapa faktor penyebab obesitas antara lain asupan makanan berlebih yang berasal dari jenis makanan olahan serba instan, makanan jajanan seperti makanan cepat saji (burger, pizza, hot dog). Faktor penyebab obesitas lainnya adalah kurangnya aktivitas fisik baik kegiatan harian maupun latihan fisik terstruktur. Kurangnya aktivitas fisik dan kehidupan yang disertai stress dapat mempengaruhi meningkatnya masalah gizi lebih (obesitas). ${ }^{10}$ Obesitas merupakan salah satu faktor resiko terjadinya asam urat. Penyakit asam urat lebih sering menyerang penderita yang mengalami kelebihan berat badan lebih dari 30\% dari berat badan ideal. Seseorang dengan berat badan lebih berkaitan dengan kenaikan kadar asam urat dan menurunnya ekskresi asam urat melalui ginjal. ${ }^{11}$

Hasil penelitian ini menunjukan $56 \%$ remaja obesitas mengalami hiperurisemia. 16\% siswa laki-laki dan 40\% siswa perempuan (Tabel 2).

Pada penelitian yang dilakukan di kota Tondano, prevalensi remaja obesitas yang mengalami peningkatan asam urat adalah $36,7 \%$, sedangkan pada penelitian di kota Tomohon prevalensinya adalah sebesar 35\%. Hal ini menunjukan prevalensi peningkatan asam urat pada remaja obesitas di kota Bitung lebih tinggi dibandingkan dengan penelitian-penelitian tersebut.

Asam urat merupakan produk akhir metabolisme purin yang berasal dari metabolisme dalam tubuh/faktor endogen (genetik) dan dari luar tubuh/faktor eksogen (sumber makanan). Asam urat sangat erat kaitannya dengan pola makan. Umumnya karena pola makan yang tidak seimbang. ${ }^{11}$ Periode remaja merupakan tahap transisi dari anak-anak menuju dewasa. Pada periode ini terjadi banyak perubahan, salah satu perubahan adalah perilaku dalam pemilihan makanan yang dipengaruhi oleh keluarga, teman sebaya dan lingkungan. Remaja akan cenderung mengkonsumsi makanan cepat saji. ${ }^{12}$ Salah satu faktor yang dapat mempengaruhi kadar asam urat adalah makanan yang mengandung tinggi purin. $^{13}$ Pengelompokkan makanan berdasarkan kandungan purin adalah sebagai berikut: Golongan A: makanan yang mengandung purin tinggi (150-800 mg) yaitu jeroan, udang, remis, kerang, sardine, herring, ekstrak daging (abon, dendeng), ragi (tape), alkohol serta makanan dalam kaleng. Golongan B: makanan yang mengandung purin sedang (50-150 mg) yaitu ikan yang tidak termasuk golongan $\mathrm{A}$, daging sapi, kacang-kacangan, kembang kol, bayam, asparagus, buncis, jamur, daun singkong, daun pepaya dan kangkung. Golongan C: makanan yang mengandung purin lebih ringan (0-50 mg) yaitu keju, susu, dan telur. $^{13}$

Gaya hidup dikota yang serba praktis memungkinkan masyarakat modern sulit untuk menghindari fast food yang banyak mengandung kalori, lemak, dan kolesterol. Kurangnya aktivitas fisik dan kehidupan yang disertai stres mulai menunjukkan dampak dengan meningkatnya masalah obesitas. Kesalahan dalam memilih makanan dan kurangnya pengetahuan tentang gizi akan mengakibatkan timbulnya masalah gizi yang akhirnya mempengaruhi status gizi. Status gizi yang baik hanya dapat tercapai dengan pola makan yang baik, yaitu pola makan yang didasarkan atas prinsip menu seimbang, alami dan sehat. ${ }^{13}$

\section{SIMPULAN}

Prevalensi obesitas pada remaja di kota Bitung adalah 22,8\% dan remaja obesitas yang memiliki kadar asam urat diatas batas normal adalah 56\% dan yang normal adalah $44 \%$. 


\section{DAFTAR PUSTAKA}

1. Price S, Wilson L. Patofisiologi. Edisi ke-6. Jakarta: EGC; 2006. h. 1402

2. Misnadiarly. Rematik: Asam UratHiperurisemia, Arthritis Gout. Jakarta: Pustaka Obor Populer: 2007

3. Sipayung E, Warouw S, Manoppo J. Hubungan Obesitas Dengan Peningkatan Asam Urat Pada Remaja Di Sekolah Menengah Pertama. Jurnal Ilmu Kesehatan Anak Fakultas Kedokteran Unsrat. 2014:2.

4. Setyowati, Syamsiatun N, Herawati. Obesitas, Pola Konsumsi Sumber Purin dan Lemak sebagai Faktor Risiko Terjadinya Asam Urat (Gout) pada Pasien Rawat Jalan di Puskesmas Gamping II Sleman Yogyakarta. Jurnal Nutrisi. 2014; 2:1.

5. Lampus B, Pandelaki A, Kant I. Gambaran Kebiasaan Makan Masyarakat di Perumahan Allandrew Permai Kelurahan Malalayang I Lingkungan XI Kota Manado. Jurnal Kedokteran Komunitas dan Tropik. 2013; 1:2.

6. Wijayanti D. Analisis Faktor Penyebab Obesitas Dan Cara Mengatasi Obesitas Pada Remaja Putri. Jurnal Ilmu Keolahragaan Universitas Negeri Semarang. 2013:1.

7. Rosita I, DH D, M Kuswandewi. Konseling GiziTranstheoritical Model Dalam Mengubah Perilaku Makan
Dan Aktivitas Fisik Pada Remaja Overweight Dan Obesitas. Jurnal Ilmu Kesehatan Masyarakat Fakultas Kedokteran Universitas Padjadjaran Bandung.

8. Novitasary M, Maluyu N, Kawengian S. Hubungan Antara Aktifitas Fisik Dengan Obesitas Pada Wanita Usia Subur Peserta Jamkesmas Di Puskesmas Wawonasa Kecamatan Singkil Manado. Jurnal eBiomedik(e-BM). 2013;1:2.

9. Sartika RAD. Faktor Resiko Obesitas Pada Anak 5-15 Tahun Di Indonesia. Jurnal Fakultas Kesehatan Masyarakat Universitas Indonesia. 2011; 15:37-38.

10. Purnamaratri A. Hubungan Beberapa Indikator Obesitas dengan Kadar Asam Urat. Jurnal Gizi. 2007

11. Lina N, Setiyono A. Analisis Kebiasaan Makan yang Menyebabkan Peningkatan Kadar Asam Urat. Jurnal Kesehatan Komunitas Indonesia. 2014; 10:1004,1006.

12. Hapsari DM. Hubungan Konsumsi Karbohidrat Sederhana dan Cairan Terhadap Kadar Asam Urat Pada Remaja Laki-laki. Jurnal Gizi. 2014

13. Arlinda S. Hubungan Konsumsi Fast Food dengan Obesitas Pada Remaja di SMP Muhammadyah 10 Yogyakarta. Jurnal Sekolah Tinggi Ilmu Kesehatan. 2015. 